\title{
Active learning materials for teaching electrochemistry
}

\author{
Thomas J. Wenzel ${ }^{1}$
}

Published online: 14 June 2018

(C) Springer-Verlag GmbH Germany, part of Springer Nature 2018

\section{Introduction}

Research shows that active classroom environments in which students work in small groups on questions or problems posed by the instructor are effective at promoting learning [1-15]. One of the tracks in the primary program supported by the US National Science Foundation aimed at improving undergraduate education is titled "Engaged Student Learning." The conclusion from these studies and reports is that instructors should move away from a classroom environment that is entirely dependent on the use of lectures.

One reason for the relative ineffectiveness of lectures for developing complex subject matter is that students often drift on and off task. This results in incomplete notes and gaps in their ability to follow the logic of the presentation [16-20]. The degree to which participants drift off task increases further into a lecture $[16,18,19]$. Excellent note-taking ability, auditory skills, and a high working memory capacity are needed for effective learning in a lecture; however, many people do not have these attributes [15]. Probing the entire audience's understanding of the material being presented is difficult. Many students may not appreciate that they do not actually understand the material being presented. Finally, many lecture participants are inhibited from asking or answering questions [15].

The inadequacy of lectures at promoting learning is apparent if one considers what is known about how people learn. Cognitive scientists have found that knowledge is constructed in the mind of the learner [21, 22]. During this construction process, new knowledge is connected to knowledge the learner already possesses [23-25]. Telling students the link between new topics and prior knowledge, as occurs in a lecture, is less effective than providing a format in which students must draw on their own knowledge first. Asking students to make appropriate connections between a new topic and prior

Thomas J. Wenzel

twenzel@bates.edu

1 Department of Chemistry, Bates College, Lewiston, ME 04240, USA knowledge may also show that many students have incorrect ideas and beliefs about fundamental concepts [26]. It is important that students with help from the instructor confront their misconceptions to promote more effective learning.

Active classroom learning involves the use of pedagogies where students engage with the material by working in small groups on questions or problems on the topic being developed. Unfortunately, there is a dearth of active learning materials available to instructors of analytical chemistry courses. Electrochemistry is a subject area covered in many undergraduate chemistry courses. In this article, I will describe a set of active learning materials suitable for the coverage of electrochemistry in the undergraduate analytical chemistry curriculum. These materials are freely available to instructors and students through the Active Learning site of the Analytical Sciences Digital Library [27]. Because materials are under the Creative Commons Copyright, instructors can use the entire unit on electrochemistry, any portions of the unit, or modify the materials in any way they wish to suit their own needs. They can freely distribute these materials or modified versions to their students.

\section{Active learning materials}

The materials developed for active learning of electrochemistry consist of a set of learning objectives, in-class question sets, textual material to support the in-class questions, and an instructor's manual [28]. Group work on in-class questions is effective for covering electrochemistry because students have prior knowledge from introductory-level courses that they need to draw upon to understand and answer the questions. The instructor's manual provides guidance to help instructors more effectively use the in-class question sets. Topics covered in the module on electrochemistry include basic concepts (the relationship between chemical energy and electrochemical potential, electrochemical cells) and electrochemical methods of analysis (ion-selective electrodes, electrodeposition, coulometry, titrimetry, and anodic stripping, linear sweep, differential pulse linear sweep, and cyclic voltammetry. A set of assessment 
questions and answers for the unit that align with the different learning levels in Bloom's taxonomy $[29,30]$ are not on the ASDL site but are available from the developer of the module on request. My approach when using these materials is to have students work in groups of 3-4 on the in-class questions before giving them the text from the module that provides the answers to those questions.

For those who cover electrochemical topics not included in the module discussed herein, there are two other resources available on the ASDL site that are freely available under the Creative Commons Copyright [31, 32]. Chapter 11 of the online textbook Analytical Chemistry 2.1 covers a wide array of electrochemical topics [31]. A text resource on basic electrochemistry topics covers fundamentals, voltammetric methods, and aspects of the hardware needed to conduct electrochemical measurements [32].

The first set of in-class questions asks the students to define the terms oxidation, reduction, oxidizing agent, and reducing agent and describe what is meant by a half reaction. They are asked to provide examples or write an appropriate expression for these and then determine whether it is possible to write an equilibrium expression for a half reaction. Most students are familiar with these concepts through a prior course in general and/or organic chemistry.

The second set of in-class questions is designed to have the students reflect back on the concept of chemical energy that they learned something about in general chemistry and perhaps physical chemistry depending on their year of study. This is achieved by having students consider a simple reaction of A rearranging to product $B$ under the constraint that the sum of the concentrations of A and B is always $2 \mathrm{M}$. Students are asked to draw a plot for the value of $\mathrm{G}$ along a reaction coordinate for different amounts of $\mathrm{A}$ and $\mathrm{B}$ for the example where the reaction has a large or small equilibrium constant. Exploring these plots allows us to examine the reason for using $\Delta \mathrm{G}$ instead of $\mathrm{G}$, the need for defining a standard state requiring the use of $\Delta \mathrm{G}^{\mathrm{o}}$ values, and the convention of using negative values of $\Delta G$ for a reaction that favors products and positive for a reaction that favors reactants. Also, it allows us to revisit the relationship in Eq. 1 that they have seen earlier in the chemistry curriculum.

$\Delta \mathrm{G}=\mathrm{RT} \ln \mathrm{K}+\mathrm{RT} \ln \mathrm{Q}$

Providing students with the relationship between electrochemical potential and free energy allows us to write and examine the Nernst equation. A presentation and discussion of the electrochemical series is then possible.

Students taking an analytical chemistry course have usually learned about the basic design of electrochemical cells in a prior course, so the next set of questions asks them to describe what they remember about an electrochemical cell, explain the processes responsible for conduction of electricity in an electrochemical cell, describe the purpose of a salt bridge and what would be put inside a salt bridge, and situations that would result in the irreversibility of an electrochemical process. For the latter question, students often propose that an electrochemical reaction that forms a gaseous product would be irreversible, allowing us to discuss ways to design an electrochemical system such that the gas will not escape the cell. The concept of an overpotential is usually something that students have not considered in any prior courses.

With an understanding of the Nernst equation and electrochemical cell, students are given a set of conditions for the reaction and asked to calculate the standard state potential and equilibrium constant. Then, they are asked to calculate the cell potential for a set of non-standard state conditions. Finally, since one of the half reactions includes $\mathrm{H}^{+}$, they are asked to calculate the cell potential at higher $\mathrm{pH}$ to examine the significant effect that $\mathrm{pH}$ has on cell potential.

Having developed background concepts of electrochemistry, the remainder of the unit addresses a number of electroanalytical methods. The first is on ion-selective electrodes. For this topic, students are given the text in advance and expected to read it in preparation for the class where we discuss the topic. Each of the ensuing areas is prefaced with a brief discussion of the nature of how the method is performed, and then students are given questions to work on in groups aimed at developing additional attributes of the technique. For electrogravimetry or coulometry, this involves determining whether certain species at certain concentrations will interfere with the plating of an analyte. One important point of this calculation is for the students to realize that the reduction potential needed to plate a metallic species increases as the concentration decreases, making it more likely that other species might interfere. For coulometry, the students are first asked to draw the plot that would be obtained for current as a function of time if a constant potential is applied, and then asked how they relate the outcome of the plot to concentration. The next question asks them to identify the advantages of coulometry over electrogravimetry.

In addition to classical redox titrations using a colorimetric indicator, the methods of coulometric, amperometric, and potentiometric titrations are covered. Having discussed a classical redox titration and the way in which a coulometric titration is performed, students are asked to describe the advantages of using a coulometric titration. Having described the methodology for performing an amperometric titration, students are asked to draw the plot that would be obtained if each of the following occurred using a reducing potential: (1) only the analyte undergoes a reduction at the applied potential, (2) only the titrant undergoes a reduction at the applied potential, and (3) both the analyte and titrant undergo a reduction at the applied potential. 


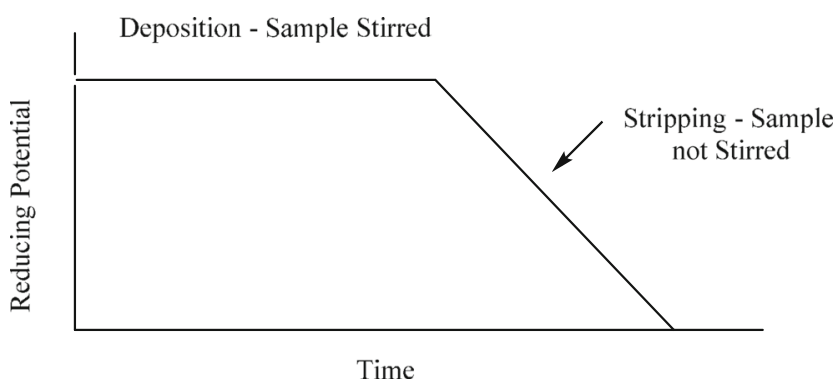

Fig. 1 Applied voltage profile for ASV

The example of the titration of iron(II) with cerium(IV) is used to develop an understanding of a potentiometric titration. The concept of a junction potential has been previously discussed in the development of electrochemical cells and ion-selective electrodes. The first questions are aimed at getting students to appreciate which half reaction is best for calculating the junction potential before and after the equivalence point. Students then calculate the junction potential at different points of the titration.

The general concepts of voltammetric methods are described in a brief lecture and then students are asked to consider how electrostatic migration can be eliminated in an electrochemical cell and why samples analyzed by voltammetric methods are usually purged with nitrogen or another inert gas before the analysis and maintained under an inert atmosphere during the analysis.

For anodic stripping voltammetry (ASV), students are asked to consider the analysis of a solution that contains $\mathrm{Cd}(\mathrm{II})$ and $\mathrm{Pb}(\mathrm{II})$, given the voltage profile that is applied as a function in time in Fig. 1, and asked to draw a plot of the current that would be measured in the deposition and stripping steps. They are reminded that a microelectrode is used, which is particularly important to consider in the deposition step. Earlier in the unit, the importance of using an electrode with a large surface area in electrogravimetry and coulometry was emphasized. After arriving at a suitable plot of current as a function of the applied potential, students are asked to determine what feature of the plot can be related to the

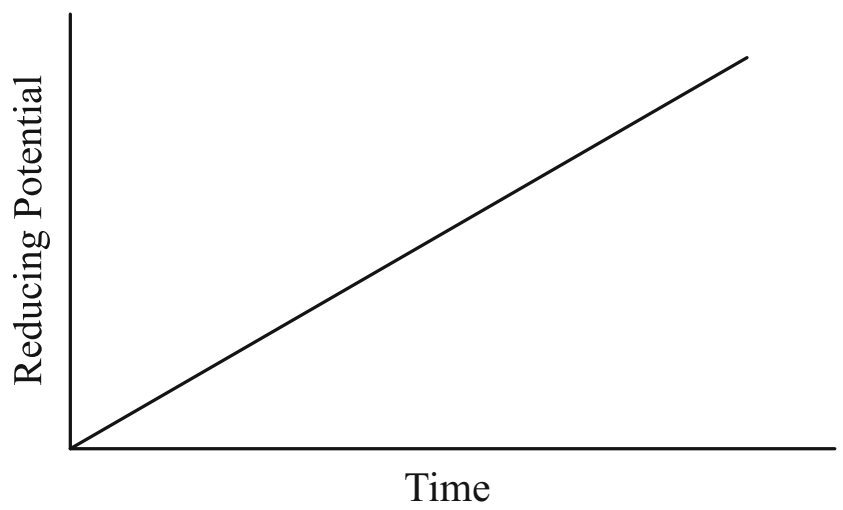

Fig. 2 Applied voltage profile for LSV

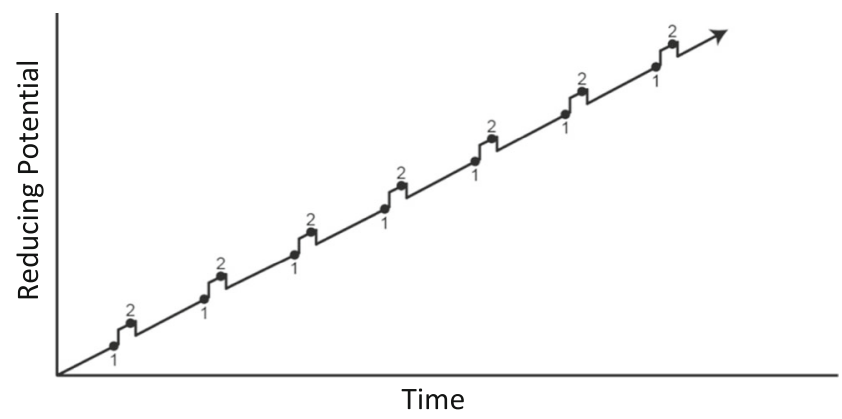

Fig. 3 Applied voltage profile for DPLSV

concentration of the metal and describe advantage(s) that ASV offers over coulometry or electroplating.

For linear sweep voltammetry (LSV), students are asked to draw the current that would be measured for a solution consisting of $\mathrm{Cd}(\mathrm{II})$ and $\mathrm{Zn}$ (II) for the voltage profile shown in Fig. 2. The problem indicates that the concentration of $\mathrm{Cd}(\mathrm{II})$ is about twice as large as that of $\mathrm{Zn}$ (II) and that the solution is stirred. They are then asked what feature of the plot can be related to concentration and what feature can be used to identify the species.

They are then given the voltage profile in Fig. 3 for differential pulse linear sweep voltammetry (DPLSV), a description of when the current is sampled and what is plotted, and asked to draw the resulting plot. The name of the method is only identified for the students after they have worked in their groups to satisfactorily draw the plot that is obtained. Finally, they are asked to identify advantages of DPLSV over LSV.

For cyclic voltammetry $(\mathrm{CV})$, students are given the voltage profile in Fig. 4 and asked to draw a plot of the current (yaxis) versus voltage (x-axis) that would be measured for a solution in which $\mathrm{Fe}(\mathrm{III})$ in ferricyanide $\left(\mathrm{Fe}(\mathrm{CN})_{6}{ }^{3-}\right)$ is reduced to $\mathrm{Fe}$ (II) during the reducing phase of the $\mathrm{CV}$ voltage profile. They are asked to contrast the plot that would be obtained for an (1) electrochemical reaction that is chemically irreversible and forms an electrochemically inactive product and (2) a reversible chemical reaction in which only the reverse reaction has an overpotential, but the potential eventually is sufficient to complete the reverse reaction. Finally, assuming a reducing potential is applied, the students are asked to propose a reaction mechanism that would explain the $\mathrm{CV}$

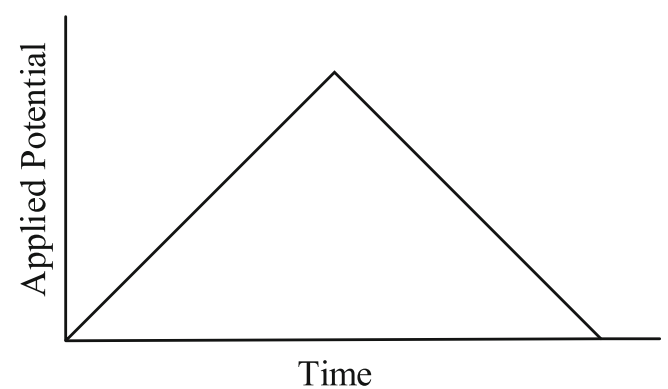

Fig. 4 Applied voltage profile for CV 


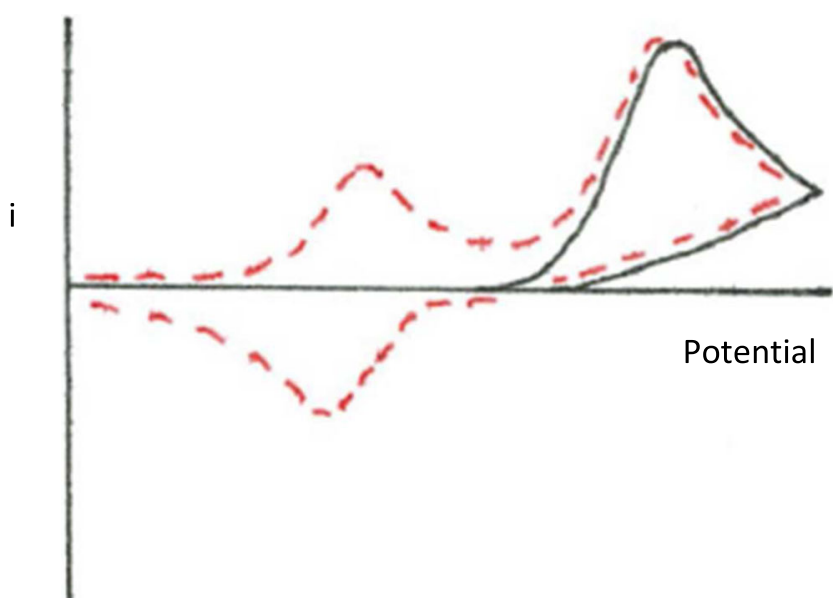

Fig. 5 Current versus potential plot for the first (solid line) and second (dotted line) voltage scan in a CV analysis

shown in Fig. 5 in which the first voltage cycle is shown as a solid line, the second voltage cycle is shown as a dotted line, and the third voltage cycle gives the same output as the dotted line.

\section{Concluding remarks}

The instructor has an especially important role in the effective use of active learning exercises described herein. The in-class exercises consist mostly of broad, open-ended questions where students need to consider knowledge from prior courses or from earlier parts of the unit that apply to the questions. Tips for effective facilitation of exercises of this nature have been described in a prior report on an active learning exercise for molecular and atomic spectroscopy [33] and are included in the instructor's module that accompanies the electrochemistry module. The in-class questions and accompanying textual material described herein can easily be modified to suit a particular instructor's needs and interests. Furthermore, only a portion of the materials need be used. The materials described herein are available through the Active Learning site on the Analytical Sciences Digital Library [27, 28] under the Creative Commons Copyright, enabling instructors to use all, some, or modified portions of them for free with their students.

Funding information I thank the National Science Foundation for supporting this work through a Transforming Undergraduate Education in STEM Award (DUE-1118600).

\section{References}

1. Freeman S, Eddy SL, McDonough M, Smith MK, Okoroafor N, Jordt $\mathrm{H}$, et al. Active learning increases student performance in science, engineering and mathematics. Proc Natl Acad Sci. 2014; www.pnas.org/cgi/doi/10.1073/pnas.1319030111
2. Thaman RG, Dhillon SK, Saggar S, Gupta MP, Kaur H. Promoting active learning in respiratory physiology — positive student perception and improved outcomes. Natl J Physiol Pharm Pharmacol. 2013;3:27-34

3. Cooper MM, Cox CT, Nammouz M, Case E, Stevens R. An assessment of the effect of collaborative groups on students' problem solving strategies and abilities. J Chem Educ. 2008;85:866-72.

4. Michael J. Where's the evidence that active learning works? Adv Physiol Educ. 2006;30:159-67.

5. Kember D, Leung DYP. The influence of active learning experiences on the development of graduate capabilities. Stud High Educ. 2005;30:155-70.

6. Anderson WL, Mitchell SM, Osgood MP. Comparison of student performance in cooperative learning and traditional lecture-based biochemistry classes. Biochem Mol Biol Educ. 2005;33:387-93.

7. Prince M. Does active learning work? A review of the research. J Engr Educ. 2004;93:223-31.

8. Cabrera AF, Crissman JL, Bernal EM, Nora A, Terenzini PT, Pascarella ET. Collaborative learning: its impact on college students' development and diversity. J Coll Stud Dev. 2002;43:20-34.

9. Gosser DK, Cracolice MS, Kampmeier JA, Roth V, Strozak VS, Varma-Nelson P, editors. Peer-led team learning: a guidebook. Upper Saddle River: Prentice-Hall; 2001.

10. Bowen CW. A quantitative literature review of cooperative learning effects on high school and college chemistry achievement. J Chem Educ. 2000;77:116-9.

11. Bransford J, Brown AL, Cocking RR. How people learn: brain, mind, experience and school. Washington, DC: National Academies Press; 2000.

12. Spencer JN. New directions in teaching chemistry: a philosophical and pedagogical basis. J Chem Educ. 1999;76:566-9.

13. Springer L, Stanne ME, Donovan SS. Effects of small-group learning on undergraduates in science, mathematics, engineering, and technology: a meta-analysis. Rev Educ Res. 1999;69:21-51.

14. Allen DE, Duch BJ, Groh SE. New directions in teaching and learning, No. 68. San Francisco: Jossey-Bass Publishers; 1996. p. 43-52.

15. Johnson DW, Johnson RT, Smith KA. Cooperative learning: increasing college faculty instructional productivity. ASHE-ERIC higher education report No 4. Washington, DC: The George Washington University, Graduate School of Education and Human Development; 1991.

16. Pollio H. What students think about and do in college lecture classes. In: Teaching-learning issues. Knoxville: University of Tennessee, Learning Research Center; 1984. p. 3-18.

17. Penner JG. Why many college teachers cannot lecture: how to avoid communication breakdown in the classroom. Springfield: Charles C. Thomas; 1984.

18. Stuart J, Rutherford RJD. Medical student concentration during lectures. Lancet. 1978;2:514-6.

19. Verner C, Dickinson G. The lecture: an analysis and review of research. J Educ Psychol. 1967;17:85-100.

20. Wenzel TJ. The lecture as a learning device. Anal Chem. 1999;71: 817A-9A.

21. Cooper MM. Evidence-based reform of teaching and learning. Anal Bioanal Chem. 2014;406:1-4.

22. Bodner GM. Constructivism: a theory of knowledge. J Chem Educ. 1986;63:873-7.

23. Novak JD. A theory of education. Ithaca: Cornell University; 1977.

24. Bretz SL. Novak's theory of education: human constructivism and meaningful learning. J Chem Educ. 2001; https://doi.org/10.1021/ ed078p1107.6.

25. Ausubel DP. Educational psychology: a cognitive view. New York: Holt, Rinehart, and Winston; 1968.

26. Singer SR, Nielsen NR, Schweingruber HA. Discipline-based education research: understanding and improving learning in 
undergraduate science and engineering. Washington DC: National Academies Press; 2012.

27. Analytical Sciences Digital Library. http://www.asdlib.org. Accessed on 7 May 2018; Curriculum materials described herein. http://community.asdlib.org/activelearningmaterials/. Accessed on 7 May 2018.

28. Electrochemical methods of analysis. http://community.asdlib.org/ activelearningmaterials/electrochemical-methods-of-analysis/. Accessed on 7 May 2018.

29. Bloom BS. Taxonomy of educational objectives: the classification of educational goals: handbook I, cognitive domain. New York: Longmans, Green; 1956.

30. Anderson LW, Krathwohl DR, Bloom BS. Taxonomy for learning, teaching and assessing. A revision of Bloom's taxonomy of educational objectives. New York: Longman Publishing Group; 2000.

31. Analytical chemistry 2.0 online textbook. http://community.asdlib. org/activelearningmaterials/analytical-chemistry-2-0-onlinetextbook/. Accessed on 7 May 2018.

32. Analytical electrochemistry: the basic concepts. http://community. asdlib.org/activelearningmaterials/analytical-electrochemistry-thebasic-concepts/. Accessed on 7 May 2018.

33. Wenzel TJ. Active learning materials for molecular and atomic spectroscopy. Anal Bioanal Chem. 2014;406:5245-8.

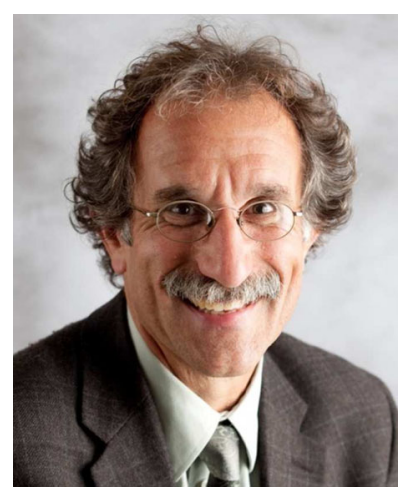

Thomas J. Wenzel is the Charles A. Dana Professor of Chemistry at Bates College in Lewiston, ME. He currently carries out research with the aid of undergraduate students in the area of chiral NMR shift reagents. His research accomplishments were recognized with the 2010 American Chemical Society Award for Research at an Undergraduate Institution. He is active in efforts to reform the undergraduate analytical chemistry curriculum to include inquiry- and project-based experiences. His educational activities were recognized through receipt of the 1999 J.C. Giddings Award for Excellence in Education sponsored by the Analytical Division of the American Chemical Society. More information about his activities can be found at http://www.bates.edu/ chemistry-biochemistry/faculty/thomas-wenzel/. 